\title{
EMOTIONAL PROBLEMS AND SLEEP DISTURBANCES IN PARAMEDICS IN THE ERA OF THE COVID-19 PANDEMIC
}

DOI: 10.36740/WLek202107133

\author{
Kamil Piotr Marczewski ${ }^{1}$, Magdalena Piegza ${ }^{2}$, Alicja Gospodarczyk' ${ }^{1}$, Robert Pudlo ${ }^{2}$, Krystyn Sosada ${ }^{1}$ \\ 'DEPARTMENT OF EMERGENCY MEDICINE, FACULTY OF MEDICAL SCIENCES IN KATOWICE, MEDICAL UNIVERSITY OF SILESIA, KATOWICE, POLAND \\ 2DEPARTMENT OF PSYCHIATRY, FACULTY OF MEDICAL SCIENCES IN ZABRZE, MEDICAL UNIVERSITY OF SILESIA, KATOWICE, POLAND
}

\begin{abstract}
Infectious diseases have accompanied mankind for centuries, and the effects of their dramatic course are felt on many levels of everyday life. The COVID-19 pandemic caused by SARS-CoV-2 virus infection carries a tremendous psychological burden for both those infected and health care workers. Particularly vulnerable to psychological strain are paramedics who have direct contact with and caring for patients infected with coronavirus. From a review of the literature, it is known that Emergency Medical Team members, as a result of the stress experienced during a pandemic, manifest symptoms such as depression, anxiety, and sleep disturbances. In order to limit the adverse impact of the pandemic on the mental condition of this professional group, it is necessary to create appropriate conditions for solitary rest, relaxation and satisfaction of basic needs such as: food, sleep and protective clothing. An important role is also played by unrestricted access to psychological support in the broad sense of the word and often also to psychiatric care.
\end{abstract}

KEY WORDS: paramedics, COVID -19 pandemic, sleep disorders, depression, anxiety

Wiad Lek. 2021;74(7):1754-1757

\section{INTRODUCTION}

The most serious of the current global health problems is the COVID-19 pandemic caused by SARS-CoV-2 virus [1, 3 ]. By 03.03.2021, a total of 115 million cases were registered worldwide, of which 2.55 million patients died (in Poland -1.72 million and 40 thousand, respectively) [2]. The COVID-19 pandemic, similarly to previous epidemics, causes an enormous physical and psychological burden on the infected individuals and health care workers $[4,5]$. For this reason, the authors of the present study analyzed the problem of emotional and sleep disorders among the employees of Emergency Medical Teams. Based on the available literature, a review of current knowledge on the prevalence of depression, anxiety and sleep disorders in paramedics is presented.

Medical Emergency Teams (EMTs) are responsible for providing assistance in emergencies. They constitute a unit of the State Medical Rescue System, which provides out-of-hospital as well as in-hospital care (depending on the situation) with a constantly expanding scope of practice [6]. According to the data of the Central Statistical Office, as of December 31,2019, the number of medical personnel included in medical emergency teams was 12.7 thousand, which is 1.1 thousand less than in the previous year [7]. In Poland, from the beginning of the pandemic until 05.01.2021, 80 thousand health care workers were infected with the SARS-CoV-2 virus, and 145 of them died due to COVID-19. The highest number of deaths was recorded among doctors -66 and nurses -51 . In the case of paramedics, the number of infections was more than 3 thousand, of which 5 died, and almost 10 thousand paramedics were in quarantine at that time [8].

The rapid transmission of SARS-CoV-2 proved to be a major challenge to the health care system both because of the rate of increase in the number of infected persons and because of the deterioration of the mental health of the general public due to life-limiting conditions [9]. The COVID-19 pandemic also revealed shortcomings in health care. The ever-increasing number of patients, excessive workload due to staff shortages, inadequate personal protective equipment, and lack of adequate support may further exacerbate the experience of stress $[4,10]$. Previous reports suggest that during a pandemic, increased levels of anxiety, depression, stress, insomnia and chronic fatigue are observed among medical workers. These disorders occur primarily in nurses, more often in women than men. Studies conducted during the SARS epidemic in 2003 showed that health care workers feared for their own health, that of their families, colleagues and co-workers; they felt insecure and stigmatized, and additionally reported aversion to work due to work overload [11]. The work in the Emergency Medical Service involves constant readiness to go to the site of an accident, provide efficient, quick and professional help to patients whose health or life is at risk. If necessary, rescuers organize the evacuation of people from danger places, working under time pres- 
sure and in difficult conditions. Therefore, in addition to the required knowledge, it is important that paramedics have the appropriate mental aptitude such as self-control, resistance to stress, the ability to work in a team and the ability to take decisive action, because the life of the victims depends on their actions. It has been demonstrated that the work of paramedics is highly stressful compared to other professions $[12,13]$.

\section{THE AIM}

The aim of this paper is to review the current literature on the prevalence of depression, anxiety and sleep disorders among Emergency Medical Team personnel during the COVID-19 pandemic outbreak.

\section{REVIEW AND DISCUSSION}

\section{STRESS FACTORS}

In a study conducted by Frydrysiak et al. it was shown that stress at work of the Emergency Medical Service personnel is a very significant problem, leading to decreased concentration, insomnia, irritability, gastric problems and headaches. As many as $33 \%$ of the respondents reported that the mere sound/light signal of the ambulance induces fear and anxiety in them. A source of stress for all respondents is being present when a patient dies. On the other hand, in terms of duties and tasks, the most stressful is monitoring and observing patients in a life/health-threatening condition, in second place - informing patients' families about their condition or death, and in third place - fear of confusing the dose and type of medication administered. According to the respondents, the stressful factors are mainly associated with high responsibility, demanding attitude, aggression of patients, necessity to make quick decisions and peer pressure [14].

Binczycka-Anholcer et al. also reached similar conclusions. Their results showed that $24 \%$ of respondents experienced stress every day during their duties and 33\% once a week [15]. Among the ways of coping with stress, listening to music and playing sports during leisure time were found to be the best methods [14].

During the COVID-19 pandemic, the global shutdown of communities, education, and industry causes additional mental deterioration, with ultimate consequences still to come [16]. The relatively short duration of the pandemic and the lack of availability of appropriate medications to control the course of the disease are other reasons for the high levels of anxiety associated with the fear of self-infection and the pressure on emergency medical workers $[17,18]$. The situation is also not improved by the fact that members of the emergency medical services (EMTs) encountering patients with COVID-19 on a daily basis constantly compare the spread and course of the infection with other diseases and for this reason also feel increased anxiety related to the threat to their own health and lives [19].
In a study conducted by Shahzad et al. it was shown that the prospect of contracting COVID-19 causes symptoms of anxiety, depression, and emotional exhaustion in paramedics, which is due to both excessive workload and fear of infection resulting from inadequate protection in the work environment. In addition, the risk of quarantine and isolation, lack of contact with family members and perceived stress exacerbate the psychological problems described above $[18,20]$.

Lerner et al. noted that at the beginning of the COVID-19 outbreak, there was a significant decrease in emergency department trips in the United States. At the same time, the rate of on-scene deaths among patients calling 911 doubled, with a reduced rate of injuries [21]. It is likely that the reduction in calls is due to lifestyle changes associated with restrictions and orders to remain at home. At the same time, the increase in telemedicine participation may have potentially reduced the use of emergency medical services (EDs) and hospital transport. It is possible that the increased number of deaths is due to the decreased frequency of patient visits to the Hospital Emergency Department (ED), even for conditions that require immediate medical attention, driven by concerns about infection in the hospital [22,23]. Garcia et al. noted a pandemic decrease in cardiac catheterization procedures for ST-segment elevation myocardial infarction by $38 \%$ between January 1 , 2019 and March 31, 2020. Similar decreases in admissions for acute coronary syndrome have been reported in Italy $[24,25]$. In addition, less frequent emergency department calls for stroke cases have been recorded [26]. Other studies have confirmed reduced use of emergency medical services during the pandemic among patients with cardiovascular complaints, despite the presumed similar prevalence of cardiovascular disease during this period [23]. Individuals with significant somatic burden currently require more complex care and greater skill from medical services, which is also due to a failure to seek early help in the treatable stages of the disease. These factors create additional stress and anxiety among paramedics and have negative consequences for their health and well-being $[21,27]$.

\section{SYMPTOMS OF DEPRESSION \\ AND ANXIETY AND INSOMNIA}

Based on the results of studies on previous SARS or Ebola outbreaks, it can be concluded that increased workload, physical exhaustion, inadequate personal protective equipment, transmission of infections in the hospital, and having to make ethically difficult decisions about providing first aid to those most in need can have a dramatic impact on the physical and mental state of paramedics [28]. In a study by Liu et al, it was shown that potential outbreaks and the associated risk of isolation, risk of infecting oneself, friends or relatives lead to long-term adverse mental health consequences such as anxiety, depression and insomnia [29]. Using data obtained from a review and meta-analysis of 13 papers with a total of 33,062 participants, the psychosocial impact of COVID-19 on "frontline" health care workers 
was determined. The occurrence of phenomena such as anxiety, depression, and insomnia was assessed. Evidence of anxiety symptoms was found in 12 studies, with a total prevalence of $23.2 \%$, and depression in 10 studies with a prevalence of $22.8 \%$. Differences were revealed between genders and occupations. A higher rate of affective disorders was reported by women, and among staff, by nurses. Insomnia has been evaluated in 5 studies, in which its frequency was estimated at 34.3\% [5,30-32].

Based on questionnaires administered from January 29 , 2020 , to February 4, 2020, to health care workers working in Wuhan, Kang et al. demonstrated that psychological support is necessary, even for mild mental disorders. The questionnaire consisted of the following items: demographics, mental health assessment, risks associated with direct and indirect exposure to COVID-19, available psychiatric care services, psychological needs, and self-assessment of health status compared to the pre-COVID-19 outbreak state. The results obtained from this study revealed that continuous psychiatric care reduces the risk of developing complications arising in response to stress. It was also found that individuals who did not receive therapeutic counseling manifested more severe psychiatric disorders [33].

In contrast, Chan et al. demonstrated that strong support from family and friends, as well as supervisors and co-workers, plays a major role in protecting against the effects of acute stress. Similarly, other factors such as proper work organization, provision of personal protective equipment, and clear communication of directives promote psychological well-being among health care workers [34]. In a study conducted by Phua et al. stress relief in the form of telling jokes was found to have a positive effect on paramedics, resulting in a lower incidence of post-traumatic stress disorder (PTSD) [35].

\section{CONCLUSIONS}

The above results confirm that a high percentage of health care workers experience significant levels of anxiety, depression, and insomnia during the COVID-19 pandemic. This highlights the need for timely targeted interventions to effectively treat milder clinical mood symptoms or subthreshold syndromes before they develop into more complex and persistent psychopathological reactions . Given the information cited above, it is important to offer early assistance and develop appropriate intervention strategies to prevent psychiatric disorders in emergency responders during the COVID-19 pandemic. For example, virtual clinics, remote psychological therapies, risk monitoring technologies, or hotlines/chat rooms available around the clock with the ability to obtain necessary information seem to be an interesting solution. When working long hours, rescuers should be guaranteed a place to rest alone, relax and meet basic needs such as food, sleep, protective clothing. This was confirmed in a study conducted by Chen et al. which included medical personnel working at "Xiangya Hospital of Central South University" in Hunan Province. Nationwide telephone and Internet lines have been established in China, but there is no evidence to support their effectiveness [36].
Currently, we have insufficient research on psychiatric disorders occurring during a pandemic among paramedics. However, taking into account previous experience and the current global pandemic situation in the world and its likely further impact on mental health, the necessity of special care for health professionals who have direct contact with the patient with COVID-19 is imposed.

\section{REFERENCES}

1. Szambor T, Masiak J, Urbańska A et al. Związek pomiędzy sprawowaniem opieki medycznejnad osobamizchorobą COVID-19a zdrowiem psychicznym pracowników ochrony zdrowia. Pol J Public Health. 2019;129(4):145-147.

2. Ministerstwo Zdrowia. 2020. Mapa zarażeń koronawirusem (SARSCoV-2).]; [https://www.gov.pl/web/koronawirus/wykazzarazenkoronawirusem-sars-cov-2; download 15.04.2021].

3. Huang C, Wang Y, Li X. Clinical features of patients infected with 2019 novel coronavirus in Wuhan, China. Lancet. 2020:395:497-506.

4. Heitzman J. Wpływ pandemii COVID-19 na zdrowie psychiczne. Psych Pol. 2020;54(2):187-198.

5. Pappa S, Ntella V, Giannakas T et al. Prevalence of depression, anxiety, and insomnia among healthcare workers during the COVID-19 pandemic: A systematic review and meta-analysis. Brain, Behavior, and Immunity. 2020(88):901-907.

6. Whitfield S, MacQuarrie A, Boyle M. Trained, ready but under-utilised: Using student paramedics during a pandemic. AustralJ Paramed. 2020;17.

7. Pomoc doraźna i Ratownictwo Medyczne w 2019. [download 15.04.2021]; https://stat.gov.pl/obszary-tematyczne/zdrowie/zdrowie/ pomoc-dorazna-i-ratownictwo-medyczne-w-2019-roku,14,4.html.

8. Lechowicz-Dyl A. Ilu lekarzy zmarło z powodu koronawirusa? Ministerstwo Zdrowia podało dane. [https://www.pap.pl/aktualnosci/ news\%2 (808786\%2Cilu-lekarzy-zmarlo-z-powodu-koronawirusaministerstwo-zdrowia-podalo-dane; download 05.02.2021].

9. Mazur A, Saran T, Adamek K. Znaczenie aktywności fizycznej w prewencji pierwotnej zaburzeń depresyjnych podczas epidemii COVID-19mediacyjna rola samoregulacji. Przegląd zagadnień z fizjoterapii i sportu. Lublin: Fundacja TYGIEL;2020, p.271-285.

10. Lai J, Ma S, Wang $Y$ et al. Factors associated with mental health outcomes among health care workers exposed to coronavirus disease 2019. JAMA Netw. Open.2020; 3(3): e203976; doi: 10.1001/ jamanetworkopen.2020.3976.

11. Maunder R, Hunter J, Vincent L et al. The immediate psychological and occupational impact of the 2003 SARS outbreak in a teaching hospital. CMAJ. 2003;168(10):1245-1251.

12. Ogińska-Bulik N. Stres zawodowy w zawodach usług społecznych. Warszawa: Difin; 2006, pp. 40-60.

13. Basiński A, Holajn P, Papiernik B et al. Zespół stresu pourazowego w pracy zawodowej ratowników medycznych. Anest Rat. 2012;6:339-42.

14. Frydrysiak K, Góraj D, TrendakW et al. Analiza czynników wywołujących stres w pracy personelu Zespołów Ratownictwa Medycznego. Anest Rat. 2016;10:53-59.

15. Binczycka-Anholcer M, Lepiesza P. Stres na stanowisku pracy ratownika medycznego. Hygeia Public Health. 2011;46:455-61.

16. Whitfield S, MacQuarrie A, Boyle M. Trained, ready but underutilised: Using student paramedics during a pandemic. Austral J Paramed.2020;17.

17. LiS, Wang Y, Xue J et al. The impact of covid-19 epidemic declaration on psychological consequences: A study on active weibo users. Int J Environ Res Public Health. 2020;17:1-9. 
18. Shahzad F, Du J, Khan I et al. Perceived Threat of COVID-19 Contagion and Frontline Paramedics' Agonistic Behaviour: Employing a StressorStrain-Outcome Perspective. Int. J. Environ. Res Public Health. 2020;17(14): 5102.

19. Lai J, Ma S, Wang Y et al. Factors Associated with Mental Health Outcomes among Health Care Workers Exposed to Coronavirus Disease 2019. JAMA Netw. Open 2020;3:e203976.

20. Kang L, LiY, Hu S et al. The mental health of medical workers in Wuhan, China dealing with the 2019 novel coronavirus. Lancet Psychiatry 2020;7:e14.

21. E. Brooke Lerner E, Craig Newgard D, Clay Mann N. Effect of the Coronavirus Disease 2019 (COVID-19) Pandemic on the U.S. Emergency Medical Services System: A Preliminary Report. Acad Emerg Med. 2020;17(8):693-699.

22. Nogueira PJ, Nobre MA, Nicola PJ et al. Excess mortality estimation during the COVID-19 pandemic: preliminary data from Portugal. Acta Med Port 2020;33:376-83.

23. Satty T, Ramgopal S, Elmer J. EMS responses and non-transports during the COVID-19 pandemic. Am J Emer Med. 2021;42:1-8.

24. Garcia S, Albaghdadi MS, Meraj PM et al. Reduction in STSegment Elevation Cardiac Catheterization Laboratory Activations in the United States During COVID-19 Pandemic. J Am Coll Cardiol.2020;75(22):2871-2872.

25. De Filippo 0, D'Ascenzo F, Angelini F et al. Reduced Rate of Hospital Admissions for ACS during Covid-19 0utbreak in Northern Italy. N Engl J Med. 2020;383(1):88-89.

26. Desai SM, Guyette FX, Martin-Gill C et al. Collateral damage - Impact of a pandemic on stroke emergency services. J Stroke Cerebrovasc Dis. 2020;29(8):104988.

27. Hartnett KP, Kite-Powell A, DeVies J et al. Impact of the COVID-19 Pandemic on Emergency Department Visits - United States. MMWR Morb Mortal Wkly Rep. 2020;69:699-704.

28. Lung FW, Lu YC, Chang YY et al. Mental symptoms in different health professionals during the SARS attack: a Follow-up study. Psychiatr $Q$. 2009;80:107-116.

29. Liu X, Kakade M, Fuller CJ et al. Depression after exposure to stressful events: lessons learned from the severe acute respiratory syndrome epidemic. Compr Psychiatry. 2012;53:15-23.

30. Du J, Dong L, Wang T et al. Psychological symptoms among frontline healthcare workers during COVID-19 outbreak in Wuhan. Gen Hosp Psychiatry.2020;67:144-145.

31. Guo J, Liao L, Wang B et al. Psychological effects of COVID-19 on hospital staff: a national cross-sectional survey of china mainland. SSRN Electron. J. 2020.[download 15.04.2021];https://doi.org/10.2139/ssrn.355005
32. Huang Y, Zhao N. Generalized anxiety disorder, depressive symptoms and sleep quality during COVID-19 epidemic in China: a web-based cross-sectional survey. Psychiatry Res. 2020;288:112954.

33. Kang L, Ma S, Chen M et al. Impact on mental health and perceptions of psychological care among medical and nursing staff in Wuhan during the 2019 novel coronavirus disease outbreak: a cross-sectional study. Brain Behav Immun. 2020;87:11-17.

34. Chan A0, Huak CY. Psychological impact of the 2003 severe acute respiratory syndrome outbreak on health care workers in a medium size regional general hospital in Singapore. Occup Med. 2004;54(3):190-196.

35. Phua DH, Tang HK, Tham KY. Coping responses of emergency physicians and nurses to the 2003 severe acute respiratory syndrome outbreak. Acad Emerg. Med. 2005;12(4):322-328.

36. Chen $Q$, Liang M, LiY et al. Mental health care for medical staff in China during the COVID-19 outbreak. Lancet Psychiatry 2020;7(4):e15-e16. doi: 10.1016/ S2215-0366(20)30078-X.

\section{ORCID and contributionship:}

Kamil Piotr Marczewski - 0000-0003-4250-8235 A,B,D,E

Magdalena Piegza - 0000-0002-8009-7118 A,E-F

Alicja Gospodarczyk - 0000-0002-2881-508X ${ }^{A-D}$

Robert Pudlo - 0000-0002-5748-0063 E-F

Krystyn Sosada - 0000-0001-9084-4933 A,E-F

\section{Conflict of interest:}

The authors declare no conflict of interest.

\section{CORRESPONDING AUTHOR Kamil Piotr Marczewski \\ Department of Emergency Medicine, Faculty of Medical Sciences in Katowice, Medical University of Silesia, Katowice, Poland tel: +48733226408 \\ e-mail:kamil.marczewski112@gmail.com}

Received: 10.04 .2021

Accepted: 05.06.2021

\footnotetext{
A - Work concept and design, B - Data collection and analysis, C - Responsibility for statistical analysis, D-Writing the article, $\mathbf{E}$-Critical review, $\mathbf{F}$ - Final approval of the article
} 